\title{
Bentoso bestuburių bendrijos natūraliose ir tiesintose Merkio baseino upių atkarpose
}

\author{
Ramūnas Gegužis \\ Aleksandro Stulginskio universitetas, \\ Studentu g. 11, \\ LT-53361 Akademija, Kauno $r$. \\ El.paštas: ramunas.geguzis@gmail.com
}

Ištirta trijų Merkio baseino upių (Spengla, Amarnia, Grūda) skirtingose atkarpose (NM - natūrali miške, TM - tiesinta miške, TL - tiesinta laukuose) makrozoobentoso rūšinè sudètis ir gausumas. Natūraliose tirtų upių atkarpose miške srovès greitis ir debitas buvo didesni, o vagos užaugimas augalais ir tiesioginis saulès patekimas ị upès vagą - mažesni, palyginti su tiesintomis upių atkarpomis. Tirtụ upių atkarpose nustatyti 72 makrozoobentoso taksonai, priklausantys 48 šeimoms. 18 makrozoobentoso taksonų aptikta tik natūraliose tirtų upių atkarpose miške ir 7 - tik tiesintose tirtų upių atkarpose. Tyrimais nustatyta, kad toje pačioje upèje didžiausias bendras makrozoobentoso ir EPT (Ephemeroptera, Plecoptera, Trichoptera) (lašalai, ankstyvès, apsiuvos) taksonų skaičius buvo natūralioje upių atkarpoje miške, o mažiausias - tiesintoje atkarpoje laukuose. Natūraliose Spenglos ir Amarnios upių atkarpose dominavo apsiuvos Brachycentrus maculatus, o visų tirtų upių tiesintose atkarpose chironomidai Cricotopus algarum. Tyrimais įrodyta, kad bendras makrozoobentoso gausumas tirtų upių natūraliose atkarpose miške buvo statistiškai patikimai didesnis nei tiesintose upių atkarpose laukuose. Didžiausias bendras makrozoobentoso gausumas nustatytas Spenglos upés natūralioje atkarpoje miške (4 $180 \pm 45$ ind. $\mathrm{m}^{-2}$ ), o mažiausias - Grūdos upès tiesintoje atkarpoje laukuose $\left(640 \pm 17\right.$ ind. $\left.\mathrm{m}^{-2}\right)$. Lašalų, apsiuvų, EPT, vabalų lervų gausumas tirtų upių natūraliose atkarpose miške buvo statistiškai patikimai didesnis nei tiesintose upių atkarpose. Atsparių taršai chironomidų gausumas Spenglos ir Amarnios upių tiesintose atkarpose buvo statistiškai patikimai didesnis nei natūraliose atkarpose miške.

Raktažodžiai: makrozoobentosas, natūralios, tiesintos upių atkarpos

\section{IVADAS}

Upių ekosistemų fiziocheminę būseną ir hidrologinị režimą lemia upių vagų tiesinimas ir natūralių vandens telkinių pakrančių mišku naikinimas (Chapman ir kt., 2002; Kasangaki ir kt., 2008).

Iki 1998 m. Lietuvoje buvo iškasta 63,4 tūkst. km griovių, iš jų apie 46 tūkst. km sudarè sureguliuotos upes ir upeliai. Nustatyta, kad sureguliuotos upių ir upelių vagos šiuo metu užima $82,6 \%$, o gamtinès - tik 17,4 \% upių tinklo. Reguliuojant natūralių upių ir upelių vagas buvo panaikinti natūralūs jų vingiai, vagų skersinis profilis tapo dirbtinai suformuotas. Taip sureguliuota upe tapo tiesiniu kanalu, skirtu nuvesti iš sausinimo sistemos surinktą perteklinį vandenị (Gailiušis ir kt., 2001).
Vandens gyvūnų bendrijų sudèties pokyčius, kuriuos lèmé žmogaus veikla, dažniausiai atspindi makrozoobentosas, nes jis yra jautrus vandens kokybei ir specifiniams antropogeniniams poveikiams (Karr, Kerans, 1991; Wildhaber, Schmitt, 1998). Dauguma makrozoobentoso gyvūnų pasižymi palyginti ilgu gyvenimo ciklu (metai ar daugiau), ribotomis migravimo galimybèmis, todèl yra ypač svarbus biologinis indikatorius, atspindintis gyvenamosios aplinkos būsenos pokyčius bègant laikui ir yra ypatingai vertingas tais atvejais, kai hidrocheminiai tyrimai neleidžia išskirti suminio daugelio veiksnių poveikio (Horne, 2003).

Užsienio mokslininkų atlikti tyrimai parodè, kad buveinių iૃvairovès mažèjimas upèse turi įtakos bendram makrobestuburių ir EPT taksonų gausumui 
(Bis ir kt., 2000; Negishi ir kt., 2002; Smiley ir Dibble, 2008).

J. F. Fruget ir kt. (2001) tyrimais atskleide, kad temperatūra ir debitas yra pagrindiniai veiksniai, kontroliuojantys ilgalaikę bestuburių bendrijos dinamiką. Mokslininkų nustatyta, kad upių debito svyravimai, lemiantys dugno buveinių stabilumą, labai veikia makrozoobentoso ịvairovę ir kieki (Deathl ir kt., 1995; Vieira ir kt., 2004).

K. Arbačiausko ir kt. (2004) duomenimis, debito nebuvimas atskirais metais Graisupio upelyje turejjo neigiamos itakos bentoso bei šoniplaukų biomasei ir biotiniam indeksui. Atlikti išsamūs makrobestuburių tyrimai Vilnios upeje parodè, kad debitas turejo neigiamos ịtakos lašalų, ankstyvių ir apsiuvų gausumui bei teigiamai veikė chironomidų ir mažašerių kirmèlių kiekí (Pliūraitè, 2007). Neigiamas koreliacinis ryšys tarp upès debito ir makrozoobentoso taksonų skaičiaus bei jų gausumo nustatytas ir Lietuvos vidutinio dydžio upèse (debitas 13-55 m³/s) (Bernotienė, Višinskienè, 2008).

Žinios apie vandens bestuburių pasiskirstymo skirtinguose vandens telkiniuose ypatumus ir pagrindinius veiksnius, lemiančius vienų ar kitų vandens bestuburių gausu plitimą vandens telkiniuose, leidžia ne tik įvertinti esamą vandens telkinio būklę, bet ir prognozuoti hidrocenozių raidą kintančioje aplinkoje.

Natūralizacija Lietuvoje siejama su upių ekologinès būklès atstatymu, tačiau prieš imantis fizinių priemonių būtina ịvertinti esamą upių ekologinę būklę. Siekiant atstatyti ištiesintų upių morfologines, hidraulines ir ypač ekologines sąlygas, kurios artimos natūralioms, būtina jas renatūralizuoti. Renatūralizuojant upes suformuojamos palankesnès sąlygos natūraliai augalijai ir gyvūnijai formuotis ir kurtis.

Lietuvoje nuo melioracijos labiausiai nukentëjo mažos upès. Merkio baseino upés - tai Pietryčiu Lietuvos regiono mažo debito upès, kurios priklauso lašišiniams vandens telkiniams. Šiame darbe tirtose Merkio baseino upese yra natūrali ir tiesinta atkarpa, tarp atkarpu nèra hidrotechninių kliūčių.

Darbo tikslas - ištirti trijų Merkio baseino upių (Speglos, Amarnios, Grūdos) skirtingų atkarpų makrozoobentoso rūšinę sudètị, gausumą ir nustatyti šių parametrų priklausomybę nuo upès vagos tipo.

\section{TYRIMŲ OBJEKTAS IR METODIKA}

Makrozoobentoso mėginiai tirti 2012 m. gegužès mèn. trijose vidutinio dydžio Merkio baseino upèse: Spengloje, Amarnioje, Grūdoje. Tyrimai atlikti 7 vietose: Spenglos upeje 3 vietose - natūralioje atkarpoje miške, tiesintoje atkarpoje miške, tiesintoje atkarpoje laukuose; Amarnios ir Grūdos upese 2 vietose - natūralioje atkarpoje miške, tiesintoje atkarpoje laukuose (1 pav.). Spenglos upès tiesintoje atkarpoje méginiai imti $6,83 \mathrm{~km}$ žemiau Spenglos ežero, 9,81 km žemiau Vaitakarčmio gyvenvietès, todèl nei ežeras, nei gyvenvietė neturèjo ịtakos makrozoobentoso taksonominei sudéčiai ir gausumui.

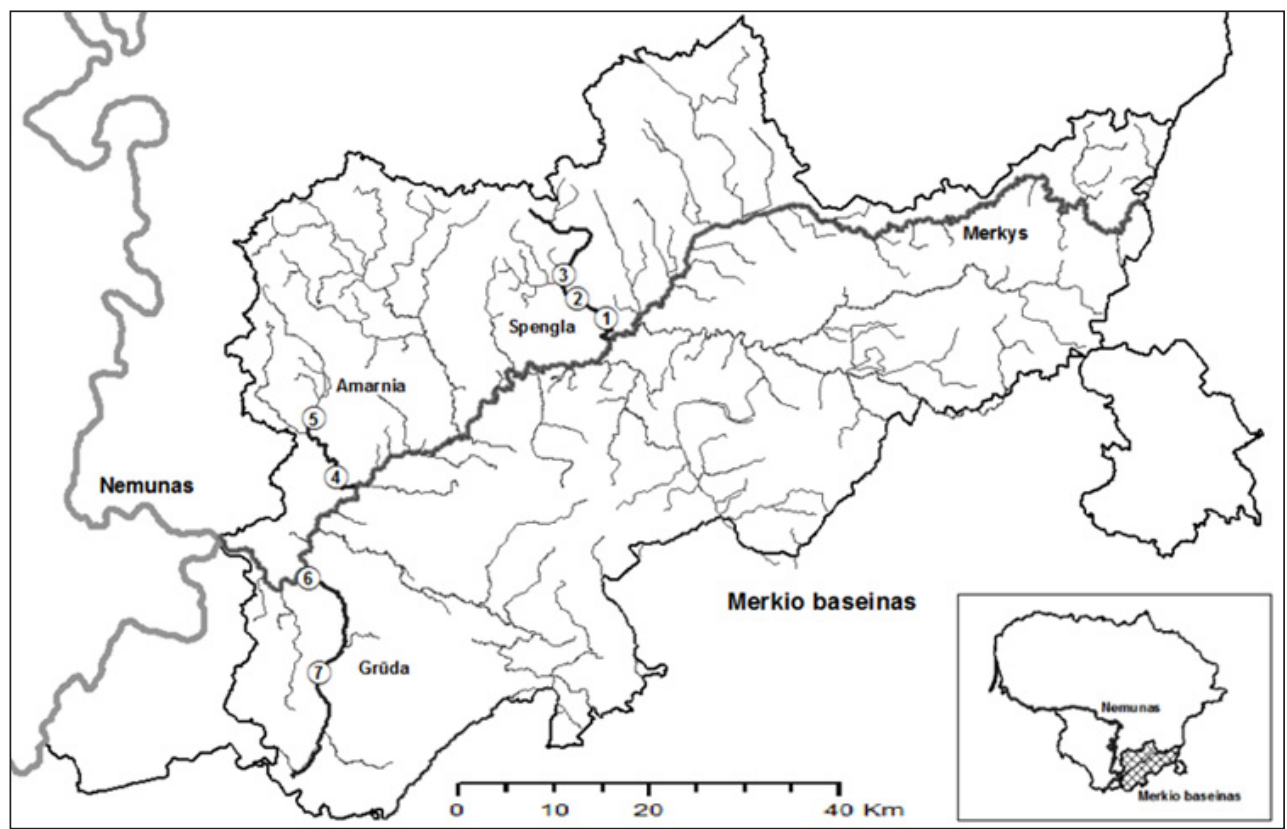

1 pav. Makrobestuburių tyrimo vietos Merkio baseino upèse (numeracija kaip ir 2 lenteleje)

Fig. 1. Study sites of macroinvertebrates in Merkys basin streams. Numbers indicate localities described in Table 2 
Makrozoobentoso mèginiai Grūdos upès tiesintoje atkarpoje imti 7,63 km žemiau Grybaulios tvenkinio, todèl tvenkinio įtakos nèra.

1 lenteleje tirtų upių ilgiai ir plotai pateikti pagal B. Gailiuši ir kt. (2001). Spengla - dešinysis Merkio intakas. Spengla prasideda Gudaraisčio pelkeje, Gudakiemio apylinkèse, $8 \mathrm{~km} \mathfrak{i}$ rytus nuo Onuškio. Spenglos upès ištakos yra Gruodžio ežere. Amarnia - dešinysis Merkio intakas, išteka iš Nedzingio ežero. Grūda - kairysis Merkio intakas, prasideda Lietuvos ir Baltarusijos pasienyje, Gudu girioje telkšančiame Grūdos ežere. Tai lygumų upè. Upių pakrantèse miške auga lapuočiai medžiai - juodalksniai.

Nustatyta, kad tiesioginis saulès patekimas $\mathfrak{i}$ vagą tirtų upių atkarpose kito nuo 15 iki $100 \%$, o vagos užaugimas augalija - nuo 5 iki $20 \%$ (2 lentelè). Nustatyta, kad minèti rodikliai tirtu upių natūraliose atkarpose miške buvo statistiškai patikimai mažesni nei tiesintose upių atkarpose (Fisher's LSD test). Visose tirtų upių atkarpose dažniausiai buvo sutinkamos šios augalų rūšys:

1 lentelè. Tirtų upių charakteristika (Gailiušis ir kt., 2001)

Table 1. Characteristics of the investigated streams (Gailiušis et al., 2001)

\begin{tabular}{c|c|c|c|c}
\hline $\begin{array}{c}\text { Nr. } \\
\text { No }\end{array}$ & $\begin{array}{c}\text { Upè } \\
\text { River }\end{array}$ & $\begin{array}{c}\text { Baseino plotas } \mathbf{k m}^{\mathbf{2}} \\
\text { Area of river-basin, } \mathbf{k m}^{\mathbf{2}}\end{array}$ & $\begin{array}{c}\text { Upės ilgis } \mathbf{k m} \\
\text { River's length, } \mathbf{k m}\end{array}$ & $\begin{array}{c}\text { Tiesintos atkarpos ilgis km } \\
\text { The length of straightened sites, } \mathbf{k m}\end{array}$ \\
\hline 1. & Spengla & 148,3 & 25,9 & $19,6-13,0$ \\
\hline 2. & Amarnia & 144,0 & 15,1 & 10,0 \\
\hline 3. & Grūda & 248,4 & 36,2 & 22,2 \\
\hline
\end{tabular}

2 lentelè. Aplinkos parametrai tirtose upių atkarpose (NM - natūrali upès atkarpa miške, TM - tiesinta miške, TL - tiesinta laukuose)

Table 2. General environment parameters of the investigated sites of the streams (NM - natural sites in the forest, TM - straightened sites in the forest, TL - straightened sites in the field)

\begin{tabular}{|c|c|c|c|c|c|c|c|c|c|c|}
\hline ص & 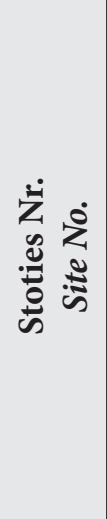 & 产 & $\begin{array}{l}\text { Vietovè } \\
\text { Locality }\end{array}$ & 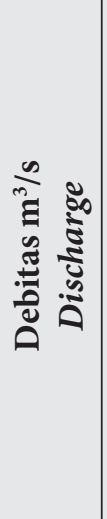 & 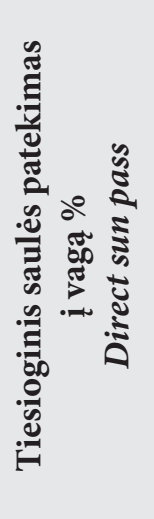 & 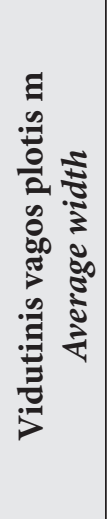 & 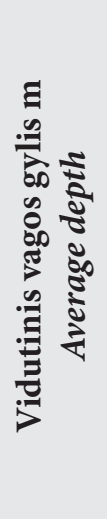 & 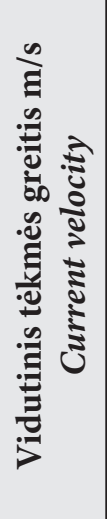 & 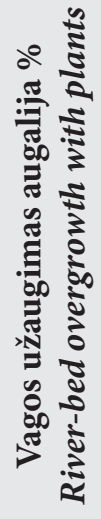 & $\begin{array}{l}\text { Dugno substratas } \\
\text { Bottom substrate }\end{array}$ \\
\hline \multirow{3}{*}{$\begin{array}{l}\frac{\pi}{00} \\
\tilde{D} \\
\text { के }\end{array}$} & 1 & NM & $\begin{array}{l}54^{\circ} 21^{\prime} 07^{\prime \prime} \mathrm{N}, \\
24^{\circ} 47^{\prime} 05^{\prime \prime} \mathrm{E}\end{array}$ & 1,34 & 20 & $7-9$ & \multicolumn{2}{|l|}{$\begin{array}{c}0,5- \\
1,2 \\
\end{array}$} & 5 & $\begin{array}{l}\text { žvyras, akmenys } \\
\text { gravel, pebble }\end{array}$ \\
\hline & 2 & $\mathrm{TM}$ & $\begin{array}{l}54^{\circ} 22^{\prime} 10^{\prime \prime} \mathrm{N}, \\
24^{\circ} 44^{\prime} 25^{\prime \prime} \mathrm{E}\end{array}$ & 1,05 & 30 & $7-10$ & $\begin{array}{c}0,5- \\
0,8 \\
\end{array}$ & 0,4 & 15 & $\begin{array}{c}\text { smèlis, žvyras } \\
\text { sand, gravel }\end{array}$ \\
\hline & 3 & $\mathrm{TL}$ & $\begin{array}{l}54^{\circ} 23^{\prime} 25^{\prime \prime} \mathrm{N}, \\
24^{\circ} 43^{\prime} 12^{\prime \prime} \mathrm{E} \\
\end{array}$ & 0,53 & 100 & $6-8$ & 0,5 & 0,3 & 15 & $\begin{array}{c}\text { smèlis-dumblas } \\
\text { sand-silt }\end{array}$ \\
\hline \multirow{2}{*}{ 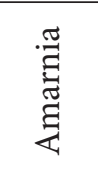 } & 4 & NM & $\begin{array}{l}54^{\circ} 14^{\prime} 21^{\prime \prime} \mathrm{N}, \\
24^{\circ} 21^{\prime} 03^{\prime \prime} \mathrm{E}\end{array}$ & 1,11 & 15 & $6-7$ & $\begin{array}{c}0,5- \\
0,9\end{array}$ & 0,6 & 5 & $\begin{array}{l}\text { žvyras, akmenys } \\
\text { gravel, pebble }\end{array}$ \\
\hline & 5 & $\mathrm{TL}$ & $\begin{array}{l}54^{\circ} 15^{\prime} 43^{\prime \prime} \mathrm{N}, \\
24^{\circ} 19^{\prime} 52^{\prime \prime} \mathrm{E}\end{array}$ & 0,54 & 100 & $5-7$ & 0,5 & 0,3 & 15 & $\begin{array}{c}\text { smèlis-dumblas } \\
\text { sand-silt }\end{array}$ \\
\hline 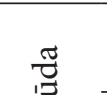 & 6 & NM & $\begin{array}{l}54^{\circ} 07^{\prime} 05^{\prime \prime} \mathrm{N}, \\
24^{\circ} 19^{\prime} 20^{\prime \prime} \mathrm{E}\end{array}$ & 1,46 & 20 & $5-8$ & $\begin{array}{c}0,6- \\
0,8 \\
\end{array}$ & 0,6 & 5 & $\begin{array}{c}\text { smèlis, akmenys } \\
\text { sand, pebble }\end{array}$ \\
\hline 迥 & 7 & $\mathrm{TL}$ & $\begin{array}{l}54^{\circ} 01^{\prime} 54^{\prime \prime} \mathrm{N}, \\
24^{\circ} 20^{\prime} 14^{\prime \prime} \mathrm{E} \\
\end{array}$ & 0,66 & 60 & $5-7$ & $\begin{array}{c}0,4- \\
0,6 \\
\end{array}$ & 0,5 & 20 & $\begin{array}{l}\text { žvyras } \\
\text { gravel }\end{array}$ \\
\hline
\end{tabular}


kanadiné elodèja (Elodea canadensis), permautalapé plūdè (Butomus umbellaus), garbiniuotoji plūdè (Potamogeton crispus), šukinè plūdè ( $P$. perfoliatus), vandeninè mèta (Mentha aquatica). Tik Spenglos upès natūralioje atkarpoje miške rastas balinis asiūklis (Equisetum fluviatile), Spenglos upès tiesintose atkarpose - mažoji plūdena (Lemna minor), o Amarnios upès natūralioje atkarpoje miške - samanos Fontinalis antipyretica.

Srovès greitis tirtu upių atkarpose kito 0,3$0,6 \mathrm{~m} / \mathrm{s}$ ribose, vandens debitas $-0,56-1,46 \mathrm{~m}^{3} / \mathrm{s}$. Srovès greitis ir debitas tirtu upių natūraliose atkarpose miške buvo statistiškai patikimai didesni nei tiesintose upių atkarpose (Fisher's LSD test).

Vandens temperatūra tirtų upių atkarpose svyravo nuo $11,9{ }^{\circ} \mathrm{C}$ iki $19,3{ }^{\circ} \mathrm{C}$ (3 lentelè). Ištirpusio deguonies kiekis upių vandenyje kito nuo 7,65 (Grūda TL) iki 10,03 mg/l (Spengla TL), amonio azotas nuo 0,0011 (Spengla NM) iki 0,0223 mg/l (Amarnia NM). Nustatyta, kad vandens kokybè pagal $\mathrm{BDS}_{7}$ (biocheminis deguonies suvartojimas per 7 paras) ir nitratų kieki geriausia buvo Grūdos natūralioje atkarpoje miške. Didžiausias nitratų kiekis nustatytas Spenglos upès tiesintoje atkarpoje laukuose. Mažiausias fosfatinio fosforo kiekis nustatytas Amarnios upès natūralioje atkarpoje miške, o didžiausias - Grūdos upés tiesintoje atkarpoje laukuose. Remiantis paviršinių vandens telkinių būklès nustatymo metodika, vandens kokybė tirtų upių atkarpose pagal visus hidrocheminius parametrus buvo labai gera arba gera (Lietuvos standartai, 2010).

Makrozoobentoso mèginiai kiekvienoje upès vietoje rinkti hidrobiologiniu tinkleliu, „spyrio“ metodu keturiuose $0,1 \mathrm{~m}^{-2}$ dugno ploteliuose $(0,40 \times 0,25 \mathrm{~m})$ (Kleemola, Söderman, 1993).

Tyrimų laikotarpiu surinkta ir išanalizuota 28 makrozoobentoso méginiai. Méginiai buvo fiksuojami $4 \%$ formalino tirpalu. Dauguma dugno makrobestuburių laboratorijoje buvo apibūdinti iki rūšies ar genties, suskaičiuoti, jų gausumas ivertintas vienam kvadratiniam metrui (ind $\mathrm{m}^{-2}$ ). Mažašerès žieduotosios kirmèlès (Oligocheta) identifikuotos iki klasès.

Makrozoobentoso rūšių identifikavimui naudoti įvairių autorių apibūdintojai (Šivickis, 1960; Pankratova, 1970, 1977, 1983; Opredelitel..., 1977, 1997, 1999, 2001).

Nustatyta kiekvienos tyrimų stoties makrozoobentoso gyvūnų rūšinè sudètis, bendras gausumas (ind. ${ }^{-2}$ ), lašalų, ankstyvių, apsiuvų, chironomidų, mažašerių žieduotujuc kirmèlių (Oligocheta), vabalų lervų (Coleoptera) bendras ir santykinis (\%) gausumas. Tyrimų vietos ivertintos pagal EPT indeksą. EPT indeksas - tai Ephemeroptera, Plecoptera, Trichoptera (lašalai, ankstyvès, apsiuvos) taksonų (rūšių ar genčių) skaičius ar santykinis individų gausumas, ar EPT individų santykis su kitais hidrobiontais yra plačiai naudojamas vandens kokybès indikatorius (Rosenberg, Resh, 1993; Sandin, Johnson, 2000; Pastuchova, 2006). Šių būrių vabzdžiai yra itin jautrūs vandens taršai, todèl jų gausumas mažeja blogèjant vandens kokybei.

Upès gylis, plotis, debitas tyrimo vietoje ir srovès greitis matuoti tiksliai tyrimo metu. Vagos dugno padengimas vandens augalija tyrimo vietoje vertintas vizualiai (\%). Tiesioginis saulès patekimas ị vagą vertintas hemisferinèmis nuotraukomis

3 lentelè. Tirtų upių atkarpų vandens hidrocheminiai parametrai (NM - natūrali upès atkarpa miške, TM - tiesinta miške, TL - tiesinta laukuose)

Table 3. The values of chemical variables of water in the investigated streams (NM - natural sites in the forest, TM - straightened sites in the forest, TL - straightened sites in the field)

\begin{tabular}{|c|c|c|c|c|c|c|c|c|c|c|}
\hline $\begin{array}{c}\text { Upès } \\
\text { Stream }\end{array}$ & $\begin{array}{c}\text { At- } \\
\text { karpa } \\
\text { Site }\end{array}$ & $\begin{array}{c}\text { Vandens } \\
\text { temperatūra }{ }^{\circ} \mathrm{C} \\
\text { Water tempera- } \\
\text { ture }\end{array}$ & $\mathrm{pH}$ & $\begin{array}{c}\mathrm{O}_{2}, \\
\mathrm{mg} / \mathrm{l}\end{array}$ & $\begin{array}{l}\mathrm{BDS}_{7}, \\
\mathrm{mg0}_{2} / 1\end{array}$ & $\begin{array}{c}\mathrm{NH}_{4}-\mathrm{N} \\
\mathrm{mg} / \mathrm{l}\end{array}$ & $\begin{array}{c}\mathrm{NO}_{3}^{-} \\
\mathrm{N}, \\
\mathrm{mg} / \mathrm{l}\end{array}$ & $\begin{array}{l}\text { N bend- } \\
\text { ras } \\
\text { mg/l } \\
\text { N total }\end{array}$ & $\begin{array}{c}\mathrm{PO}_{4}-\mathrm{P} \\
\mathrm{mg} / \mathrm{l}\end{array}$ & $\begin{array}{c}\text { P bend- } \\
\text { ras, } \\
\text { mg/l } \\
P \text { total }\end{array}$ \\
\hline \multirow{3}{*}{ Spengla } & $\mathrm{NM}$ & 16,9 & 8,2 & 9,5 & 1,56 & 0,0011 & 0,768 & 1,11 & 0,026 & 0,029 \\
\hline & TM & 17,3 & 8,2 & 9,8 & 2,74 & 0,0047 & 1,017 & 1,30 & 0,040 & 0,044 \\
\hline & $\mathrm{TL}$ & 16,1 & 8,2 & 10,0 & 3,25 & 0,0158 & 1,198 & 1,41 & 0,041 & 0,048 \\
\hline \multirow{2}{*}{ Amarnia } & NM & 19,3 & 7,8 & 8,1 & 1,70 & 0,0050 & 0,655 & 0,71 & 0,015 & 0,044 \\
\hline & $\mathrm{TL}$ & 18,1 & 8,0 & 9,0 & 2,64 & 0,0223 & 0,836 & 1,23 & 0,021 & 0,047 \\
\hline \multirow{2}{*}{ Grūda } & NM & 11,9 & 8,2 & 9,1 & 1,22 & 0,0028 & 0,249 & 0,456 & 0,051 & 0,055 \\
\hline & $\mathrm{TL}$ & 13,2 & 8,0 & 7,6 & 3,28 & 0,0170 & 0,316 & 0,741 & 0,052 & 0,061 \\
\hline
\end{tabular}


(Hemi View Canopy System prietaisas). Hemisferinems nuotraukoms analizuoti naudota kompiuterinè programa Hemi View. Vandens temperatūra, ištirpusio deguonies kiekis vandenyje ir $\mathrm{pH}$ matuoti oksimetru. Tyrimo metu taip pat paimtas vanduo hidrocheminiams tyrimams (biocheminis deguonies suvartojimas per 7 paras - $\mathrm{BDS}_{7}$, nitratinis azotas, fosfatinis fosforas, $\mathrm{N}$ bendras, $\mathrm{P}$ bendras), kurie buvo atliekami laboratorijoje.

Tirtų upių skirtingų makrozoobentoso grupių pokyčiams ịvertinti tarp natūralių ir tiesintų atkarpų naudojome tiesini modeli ANOVA. Duomenų asimetriškumui ir dispersijų homogeniškumui sumažinti visi duomenys buvo transformuoti naudojant transformaciją $\log (1+\mathrm{x})$. Vertinant EPT indekso verčiu bei atskirų makrozoobentoso gyvūnų gausumo ryši su vandens ekologiniais rodikliais, naudota
Spirmeno rangų koreliacija (Spearman Rank Correlation, rs). Skirtumui tarp natūralių ir tiesintų upių vietų reikšmingumui nustatyti panaudotas Fisher's LSD testas. Tirtų upių vietų palyginimui pagal makrobestuburių rūšinę sudetti naudotas Bray-Curtis panašumo indeksas. Šis skaičiavimas buvo atliktas naudojant PRIMER 5.2.3 paketo CLUSTER programą. Duomenys statistiškai apdoroti naudojant Excel, Statisatica 6.0 programas.

\section{TYRIMO REZULTATAI IR JŲ APTARIMAS}

Ištirtų upių atkarpose nustatyti 72 makrozoobentoso taksonai, priklausantys 48 šeimoms (4 lentelè). Gauti duomenys parode, kad 18 makrozoobentoso taksonų aptikta tik natūraliose tirtų upių atkarpose miške ir 7 - tik tiesintose tirtų upių atkarpose.

4 lentelè. Makrozoobentoso rūšinè sudètis ir sutinkamumo dažnumas (\%) tirtose upèse (NM - natūrali upès atkarpa miške, TM - tiesinta miške, TL - tiesinta laukuose)

Table 4. Composition and occurrence frequency (\%) of macroinvertebrate in the investigated streams (NM - natural sites in the forest, TM - straightened sites in the forest, $T L$ - straightened sites in the field)

\begin{tabular}{|c|c|c|c|c|c|c|c|c|c|}
\hline \multirow{2}{*}{$\begin{array}{l}\text { Būrys } \\
\text { Order }\end{array}$} & \multirow{2}{*}{$\begin{array}{l}\text { Šeima } \\
\text { Family }\end{array}$} & \multirow{2}{*}{$\begin{array}{l}\text { Gentis, rūšis } \\
\text { Genus, species }\end{array}$} & \multicolumn{3}{|c|}{ Spengla } & \multicolumn{2}{|c|}{ Amarnia } & \multicolumn{2}{|c|}{ Grūda } \\
\hline & & & NM & TM & TL & NM & TL & NM & TL \\
\hline Gordea & Gordiidae & Gordius aquaticus Linnaeus, 1758 & & & 0,6 & & 0,2 & & \\
\hline Seriata & Planariidae & Planaria sp. & 0,1 & & & & & & \\
\hline Oligochaeta & & Oligochaeta spp. & 1,2 & 7,4 & 6,6 & 5,9 & 8,8 & 2 & 14 \\
\hline \multirow[b]{2}{*}{ Hirudinea } & $\begin{array}{l}\text { Erpobdel- } \\
\text { lidae }\end{array}$ & $\begin{array}{c}\text { Erpobdella octoculata (Linnaeus, } \\
\text { 1758) }\end{array}$ & & 0,3 & 4 & & 1,7 & 0,2 & \\
\hline & $\begin{array}{l}\text { Glossiphonii- } \\
\text { dae }\end{array}$ & $\begin{array}{c}\text { Glosiphonia complanata } \\
\text { (Linnaeus, 1758) }\end{array}$ & & 0,8 & 2 & & & & \\
\hline Arachnida & Hydrace & Hydracarina spp. & 0,5 & 0,3 & 1 & & & & 0,5 \\
\hline \multirow{9}{*}{ Mollusca } & \multirow{3}{*}{ Sphaeriidae } & Pisidium supinum (Schmidt, 1851) & & 1,1 & & & 6,7 & 4 & 7,8 \\
\hline & & $\begin{array}{l}\text { Sphaerium corneum } \\
\text { (Linnaeus, 1758) }\end{array}$ & 0,6 & 4,8 & 8,7 & 0,9 & 4,2 & 2,8 & 6,8 \\
\hline & & $\begin{array}{c}\text { Sphaerium rivicola (Lamarck, } \\
1818)\end{array}$ & 0,1 & 1,5 & 0,1 & 0,3 & 0,4 & 0,7 & \\
\hline & Bithynidae & $\begin{array}{l}\text { Bithynia tentaculata } \\
\text { (Linnaeus, 1758) }\end{array}$ & 0,2 & 1,3 & 0,3 & & & & \\
\hline & \multirow{2}{*}{ Planorbidae } & Ancylus fluviatilis Müller, 1774 & 5,5 & & & 2,8 & & 3,7 & \\
\hline & & Gyraulus albus (Müller, 1774) & 1,9 & 3,1 & 0,3 & 4,3 & 1,9 & & 6,8 \\
\hline & Lymnaeidae & Radix pereger Müller, 1774 & 0,1 & 1,4 & 0,6 & 0,1 & & 0,2 & \\
\hline & Physidae & Physa fontinalis (Linnaeus, 1758) & & 0,5 & & & & 0,2 & \\
\hline & Unionidae & $\begin{array}{c}\text { Anodonta anatina (Linnaeus, } \\
1758 \text { ) }\end{array}$ & & 0,1 & & & & & \\
\hline Amphipoda & Gammaridae & Gammarus pulex (Linnaeus, 1758) & 0,1 & 9,2 & & & & & \\
\hline Isopoda & Asellidae & Asellus aquaticus (Linnaeus, 1758) & & 0,3 & 0,6 & & & & 5,7 \\
\hline \multirow{2}{*}{ Odonata } & $\begin{array}{l}\text { Calopterygi- } \\
\text { dae }\end{array}$ & $\begin{array}{l}\text { Calopteryx splendens } \\
\text { (Harris, 1782) }\end{array}$ & & & & & 0,2 & & \\
\hline & Gomphidae & $\begin{array}{l}\text { Gomphus vulgatissimus } \\
\quad \text { (Linnaeus, 1758) }\end{array}$ & & 0,8 & & 0,3 & 1,2 & 0,2 & \\
\hline
\end{tabular}


4 lentelè. (Tęsinys)

Table 4.(Continued)

\begin{tabular}{|c|c|c|c|c|c|c|c|c|c|}
\hline \multirow{2}{*}{$\begin{array}{l}\text { Būrys } \\
\text { Order }\end{array}$} & \multirow{2}{*}{$\begin{array}{l}\text { Šeima } \\
\text { Family }\end{array}$} & \multirow{2}{*}{$\begin{array}{l}\text { Gentis, rūšis } \\
\text { Genus, species }\end{array}$} & \multicolumn{3}{|c|}{ Spengla } & \multicolumn{2}{|c|}{ Amarnia } & \multicolumn{2}{|c|}{ Grūda } \\
\hline & & & NM & TM & TL & NM & TL & NM & TL \\
\hline \multirow{10}{*}{$\begin{array}{l}\text { Ephemerop- } \\
\text { tera }\end{array}$} & \multirow[b]{2}{*}{ Baetidae } & Baetis rhodani (Pictet, 1843) & & & 0,6 & 3,5 & 0,2 & & \\
\hline & & $\begin{array}{l}\text { Procloeon bifidum } \\
\text { (Bengtsson, 1912) }\end{array}$ & 5,8 & 8,9 & 1,7 & 2,4 & 6,9 & 12,1 & 14,1 \\
\hline & \multirow[b]{2}{*}{ Caenidae } & Caenis macrura Stephens, 1835 & & 6,1 & 24,4 & 0,5 & 14,2 & & \\
\hline & & $\begin{array}{c}\text { Brachycercuss harrisella Curtis, } \\
1834\end{array}$ & & & & & & & \\
\hline & \multirow{2}{*}{$\begin{array}{l}\text { Heptageni- } \\
\text { idae }\end{array}$} & Ecdyonurus dispar (Curtis, 1834) & 3,4 & & & 1,1 & & 0,2 & \\
\hline & & $\begin{array}{c}\text { Heptagenia sulphurea } \\
\text { (Müller, 1776) }\end{array}$ & 1,4 & & & 1,2 & & & \\
\hline & Ephemeridae & Ephemera danica (Müller, 1764) & & 0,9 & 6,1 & & & 0,7 & 1,1 \\
\hline & $\begin{array}{l}\text { Ephemerel- } \\
\text { lidae }\end{array}$ & Serratella ignita (Poda, 1761) & 0,2 & & & 1,7 & & & \\
\hline & \multirow{2}{*}{$\begin{array}{l}\text { Leptophlebii- } \\
\text { dae }\end{array}$} & $\begin{array}{c}\text { Paralephtophlebia cincta } \\
\text { (Retzius 1783) }\end{array}$ & & & & 0,3 & & & \\
\hline & & Habrophlebia fusca (Curtis, 1834) & & & & & & 0,9 & \\
\hline \multirow{4}{*}{ Plecoptera } & Perlodidae & Isoperla grammatica (Poda, 1761) & 0,3 & & & 8,6 & & & \\
\hline & Leuctridae & Leuctra spp. & 12,3 & & & 6,8 & & 1,4 & \\
\hline & \multirow{2}{*}{ Nemouridae } & Nemoura sp. & & & & 0,1 & & & \\
\hline & & Amphinemura sp. & 1,7 & & & 1,2 & & 1,4 & \\
\hline Hemiptera & $\begin{array}{l}\text { Aphelocheir- } \\
\text { idae }\end{array}$ & $\begin{array}{l}\text { Aphelocheirus aestivalis } \\
\text { (Fabricius, 1794) }\end{array}$ & 7 & 2,2 & 0,9 & 4,8 & & & \\
\hline \multirow{4}{*}{$\begin{array}{l}\text { Coleoptera } \\
\text { (larvae) }\end{array}$} & \multirow{2}{*}{ Elmidae } & Elmis spp. & 3,2 & 1 & 0,4 & 5,4 & & 9,3 & 1,1 \\
\hline & & Limnius volckmari (Panzer, 1793) & 12,8 & & & 11,3 & 0,2 & 8,6 & 0,5 \\
\hline & Gyrinidae & $\begin{array}{l}\text { Orectochillus villosus } \\
\text { (Müller, 1776) }\end{array}$ & 0,7 & 0,1 & 0,1 & 0,3 & & & 0,5 \\
\hline & Dytiscidae & Acilius sp. & & & & & 0,2 & & \\
\hline \multirow{2}{*}{$\begin{array}{c}\text { Coleoptera } \\
\text { (imago) }\end{array}$} & Elmidae & Limnius volckmari (Panzer, 1793) & 0,2 & & & 0,5 & & 3 & \\
\hline & Haliplidae & Haliplus spp. & & 0,3 & & 0,9 & & & \\
\hline \multirow{13}{*}{ Trichoptera } & \multirow{2}{*}{$\begin{array}{l}\text { Brachycen- } \\
\text { tridae }\end{array}$} & $\begin{array}{l}\text { Brachycentrus maculatus } \\
\text { (Fourcrog, 1785) }\end{array}$ & 26,1 & 1,9 & & & & 12,8 & \\
\hline & & $\begin{array}{c}\text { Brachycentrus subnubilus Curtis, } \\
1834\end{array}$ & 0,2 & & & 0,3 & & & \\
\hline & \multirow{4}{*}{$\begin{array}{l}\text { Hydropsy- } \\
\text { chidae }\end{array}$} & Hydropsyche siltalai Döhler, 1963 & 2,6 & 0,1 & & 1,7 & & & \\
\hline & & $\begin{array}{c}\text { Hydropsyche angustipennis Cur- } \\
\text { tis, } 1834\end{array}$ & 1,7 & 2,2 & 1,8 & 1,1 & 5,3 & 0,5 & 1,1 \\
\hline & & $\begin{array}{l}\text { Hydropsyche pellucidula Curtis, } \\
1834\end{array}$ & 2 & 1,4 & 2,2 & 2 & 6,9 & 1,4 & 3,1 \\
\hline & & Hydropsyche sp. & 1,2 & 1,2 & & 0,1 & & & \\
\hline & \multirow{2}{*}{$\begin{array}{l}\text { Hydroptili- } \\
\text { dae }\end{array}$} & Hydroptila spp. & 0,2 & 4,1 & 1,3 & 1,3 & 1,9 & 0,5 & 2 \\
\hline & & Ithytrichia lamellaris Eaton, 1873 & 0,6 & & & 1,4 & & 9,3 & \\
\hline & $\begin{array}{l}\text { Lepidos- } \\
\text { tomatidae }\end{array}$ & $\begin{array}{c}\text { Lepidostoma hirtum } \\
\text { (Fabricius, 1775) }\end{array}$ & 0,2 & 1,9 & & 4 & & & \\
\hline & \multirow{3}{*}{ Leptoceridae } & $\begin{array}{c}\text { Athripsodes aterrimus } \\
\text { (Stephens 1836) }\end{array}$ & 0,3 & 2,3 & & 0,5 & 0,8 & 1,9 & 1,1 \\
\hline & & $\begin{array}{l}\text { Athripsodes commutatus } \\
\text { (Rostock 1874) }\end{array}$ & & & & 0,3 & & & \\
\hline & & $\begin{array}{c}\text { Leptocerus tineiformis Cur- } \\
\text { tis, } 1834\end{array}$ & & & 0,1 & & 1,3 & & \\
\hline & $\begin{array}{l}\text { Limnephi- } \\
\text { lidae }\end{array}$ & Anabolia laevis Zetterstedt, 1840 & 0,6 & 0,3 & 0,3 & 0,4 & 0,8 & & 3,6 \\
\hline
\end{tabular}




\begin{tabular}{|c|c|c|c|c|c|c|c|c|c|}
\hline \multicolumn{10}{|c|}{$\begin{array}{l}4 \text { lentelè. (Tęsinys) } \\
\text { Table 4.(Continued) }\end{array}$} \\
\hline \multirow{2}{*}{$\begin{array}{l}\text { Būrys } \\
\text { Order }\end{array}$} & \multirow{2}{*}{$\begin{array}{c}\text { Šeima } \\
\text { Family }\end{array}$} & \multirow{2}{*}{$\begin{array}{l}\text { Gentis, rūšis } \\
\text { Genus, species }\end{array}$} & \multicolumn{3}{|c|}{ Spengla } & \multicolumn{2}{|c|}{ Amarnia } & \multicolumn{2}{|c|}{ Grūda } \\
\hline & & & NM & TM & TL & NM & TL & NM & TL \\
\hline \multirow{4}{*}{ Trichoptera } & $\begin{array}{l}\text { Sericostoma- } \\
\text { tidae }\end{array}$ & $\begin{array}{l}\text { Sericostoma personatum (Kir- } \\
\text { by \& Spence } 1826 \text { ) }\end{array}$ & & & & & & 6,8 & 0,5 \\
\hline & $\begin{array}{l}\text { Polycen- } \\
\text { tropidae }\end{array}$ & $\begin{array}{c}\text { Polycentropus flavomaculatus } \\
\text { Pictet, } 1834\end{array}$ & \multicolumn{7}{|c|}{0,4} \\
\hline & Ecnomidae & Ecnomus tenellus (Rambur 1842) & \multirow{2}{*}{$\begin{array}{l}0,3 \\
0,3\end{array}$} & \multirow{2}{*}{\multicolumn{2}{|c|}{0,6}} & \multicolumn{4}{|l|}{3,7} \\
\hline & $\begin{array}{l}\text { Rhyacophi- } \\
\text { lidae }\end{array}$ & $\begin{array}{c}\text { Rhyacophila nubila Zetterstedt, } \\
1840\end{array}$ & & & & & & \\
\hline \multirow[t]{8}{*}{ Neuroptera } & Sisyridae & Sisyra sp. & \multicolumn{7}{|c|}{0,1} \\
\hline & Pediciidae & $\begin{array}{l}\text { Dicranota bimaculata } \\
\text { (Schummel, 1829) }\end{array}$ & & 0,6 & & 0,6 & & & \\
\hline & Athericidae & Atherix sp. & 0,2 & & & 1,5 & & 7,7 & \\
\hline & $\begin{array}{l}\text { Ceratopogo- } \\
\text { nidae }\end{array}$ & sp. & & & 0,6 & & & & \\
\hline & Tabanidae & Tabanus sp. & & & & & & & 1,6 \\
\hline & Tipulidae & Tipula spp. & 0,6 & & & 1,5 & & 1,9 & 0,5 \\
\hline & Empididae & Hemerodromia sp. & 0,4 & & & 0,3 & & 0,7 & \\
\hline & Simuliidae & Simulium spp. & & 1,4 & & 0,9 & 3,2 & & 11,4 \\
\hline \multirow{7}{*}{ Diptera } & \multirow{7}{*}{$\begin{array}{l}\text { Chironomi- } \\
\text { dae }\end{array}$} & $\begin{array}{l}\text { Glyptotendipes (gripekoveni) } \\
\text { cauliginellus (Kieffer, 1913) }\end{array}$ & 0,1 & & & 0,4 & & & 0,5 \\
\hline & & $\begin{array}{l}\text { Demicryptochironomus vulnera- } \\
\text { tus (Zetterstedt, 1860) }\end{array}$ & & & & & 1,7 & & \\
\hline & & $\begin{array}{c}\text { Polypedilum scalaenum } \\
\text { (Schrank, 1803) }\end{array}$ & & 2 & 19,8 & & 1,5 & 0,7 & 2,6 \\
\hline & & Cladotanytarsus sp. & 0,6 & 2 & & 1,6 & 13,2 & 1,4 & 1,6 \\
\hline & & $\begin{array}{l}\text { Cricotopus algarum } \\
\text { (Kieffer, 1911) }\end{array}$ & 2,4 & 23,6 & 14,9 & 9,2 & 14,9 & 2,3 & 9,9 \\
\hline & & $\begin{array}{c}\text { Eukiefferiella coerulescens } \\
(\text { Kieffer, 1926) }\end{array}$ & 0,1 & 0,9 & & 0,3 & & & \\
\hline & & $\begin{array}{c}\text { Thienemannimyia gr. lentiginosa } \\
\text { (Fries, 1823) }\end{array}$ & & 1,1 & & 1,2 & 1,5 & 0,5 & 1,6 \\
\hline
\end{tabular}

Daugiausia rasta apsiuvų - 17 rūšių, tai 23,6 \% viso makrozoobentoso taksonų skaičiaus. Skirtingų upių atkarpose makrozoobentoso rūšiu skaičius skyrèsi. Didžiausia makrozoobentoso rūšine įvairovè nustatyta Amarnios upès natūralioje atkarpoje miške (46 taksonai), o mažiausia - Grūdos upès tiesintoje atkarpoje laukuose (25 taksonai) (2 pav.). Jautrių taršai EPT rūšių skaičius mažiausias buvo taip pat Grūdos upès tiesintoje atkarpoje laukuose (8 rūšys), o didžiausias - Spenglos upès natūralioje atkarpoje miške (21 rūšis) (2 pav.). Tyrimais nustatyta, kad toje pačioje upeje didžiausia bendra ir EPT makrozoobentoso rūšine ìvairovè nustatyta natūralioje atkarpoje miške, o mažiausia - tiesintoje atkarpoje laukuose (1 pav.). Panašius duomenis pateikia ir kiti mokslininkai (Pliūraite, Kesminas, 2010; Virbickas ir kt., 2011). Irodyta, kad upių vagų tiesinimas neigiamai veikia makrozoobentoso bendrą ir EPT rūšiu gausą, ir neturi ịtakos makrozoobentoso gausumui (Smiley, Dibble, 2008).

Nustatytas teigiamas statistiškai patikimas koreliacinis ryšys tarp bendro makrozoobentoso taksonų skaičiaus ir jautrių taršai EPT taksonų skaičiaus $(r=0,88)$. K. Arbačiausko ir kt. duomenimis (2004), bendras apibūdinamų taksonų skaičius Graistupio upelyje taip pat koreliavo su jautrių taršai taksonų skaičiumi $(r=0,69)$.

Mažašerès žieduotosios kirmèlès Oligochaeta spp., dvigeldžiai moliuskai Sphaerium corneum (Linnaeus), lašalai Procloeon bifidum (Bengtsson), apsiuvos Hydropsyche angustipennis, Curtis ir H. pellucidula, Curtis, chironomidai Cricotopus algarum (Kieffer) buvo aptikti visose tirtų upių atkarpose. Ankstyvès buvo aptiktos tik natūraliose tirtų 


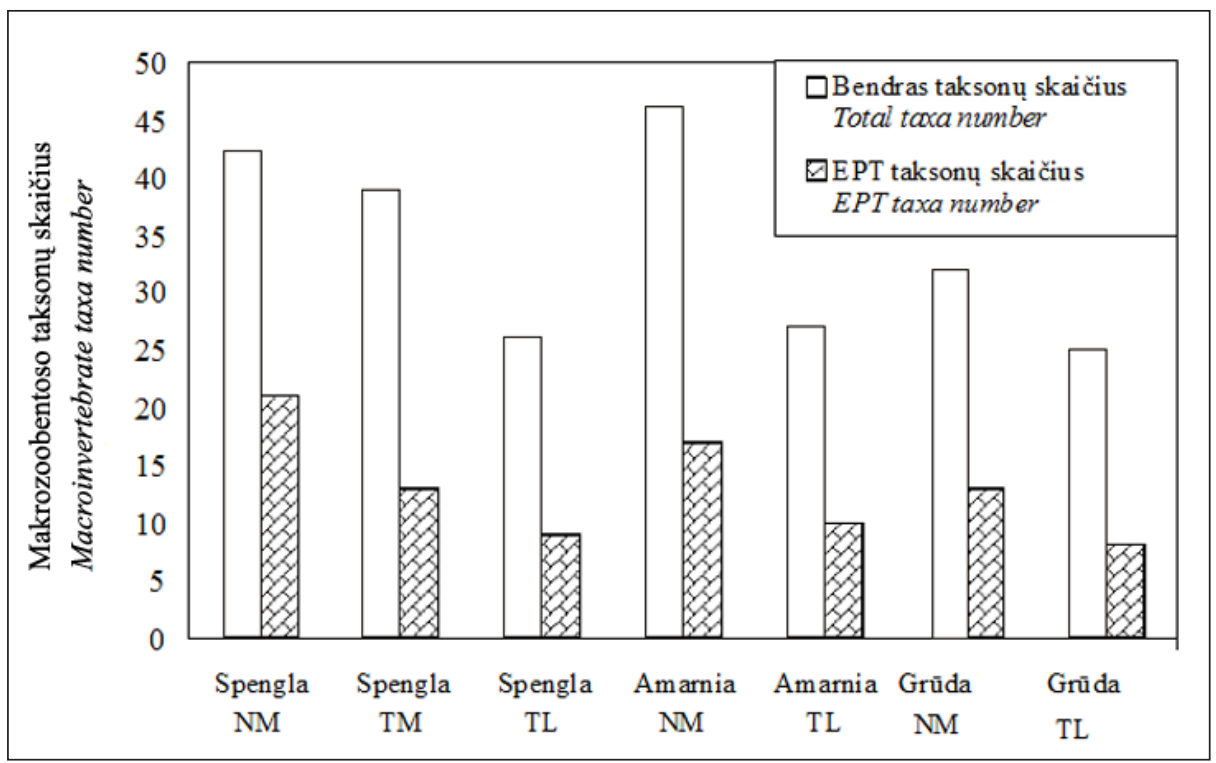

2 pav. Bendras makrozoobentoso ir EPT taksonų skaičius tirtose upèse (NM - natūrali upès atkarpa miške, TM - tiesinta miške, LT - tiesinta laukuose)

Fig. 2. Total macroinvertebrate and EPT taxa number in the investigated streams (NM - natural sites in the forest, TM - straightened sites in the forest, TL - straightened sites in the field)

upių atkarpose. Literatūros duomenimis, Nevèžio upés tiesintose atkarpose ankstyvių taip pat nerasta (Virbickas ir kt., 2011). Mokslininkų irodyta, kad Plecoptera (ankstyvès) būrio atstovai jautresni žmogaus daromai ịtakai ir natūralios aplinkos struktūros pokyčiams nei Ephemeroptera (lašalai) ar Trichoptera (apsiuvos) (Maxted ir kt., 2000), todèl neatsitiktinai ankstyvių nerasta mūsų tirtų upių tiesintose atkarpose. Didžiausia ankstyvių Leuctra spp. gausa nustatyta Spenglos upès natūralioje atkarpoje miške (12,3 \% viso gausumo), o ankstyvių rūšis Isoperla grammatica (Poda) gausiausiai sutinkama Amarnios upès natūralioje atkarpoje miške (8,6 \% viso gausumo).

Tirtos upès buvo skirtingos pagal vagos struktūrą, todèl kai kurios makrobestuburių rūšys buvo aptiktos tik vienoje iš tirtų upių. Šoniplaukos Gammarus pulex (Linnaeus) buvo aptiktos tik Spenglos upès natūralioje ir tiesintoje atkarpose miške ir jų santykinè gausa tiesintoje atkarpoje $(9,2 \%$ viso gausumo) buvo daug didesnè nei natūralioje atkarpoje (0,1\%). Grūdos upèje nerasta blakių Aphelocheirus aestivalis (Fabricius), kurios Spenglos upès natūralioje atkarpoje miške sudare $7 \%$ viso makrozoobentoso gausumo.

Spenglos upès natūralioje atkarpoje miške vyravo apsiuvos Brachycentrus maculatus (Fourcrog)
(26,1 \% viso makrozoobentoso gausumo). Minèta apsiuvų rūšis buvo gausiai sutinkama ir Grūdos upès natūralioje atkarpoje miške $(12,8 \%)$. Tyrimais nustatyta, kad apsiuvų rūšies Brachycentrus maculatus (Fourcrog) tirtų upių tiesintose atkarpose laukuose nèra. Spenglos ir Grūdos upių natūraliose atkarpose miške vandens debitas didesnis nei tiesintose atkarpose, kas ir lèmé šių apsiuvų gausumą. Kitų mokslininkų duomenimis, apsiuvų Brachycentrus maculatus (Fourcrog) gausa sietina su šaltavandenėmis stipresnès srovès upèmis (Czachorowski, Pietrazk, 2003). Vabalų lervos Limnius volckmari, Panzer Spenglos upès natūralioje atkarpoje miške sudare $12,8 \%$ (viso makrozoobentoso gausumo), Amarnios - 11,3 \%, Grūdos - 8,6 \%. Tiesintose upių atkarpose šios vabalų rūšies gausa kito nuo 0 iki 0,5 \%. T. Virbicko ir kt. (2011) duomenimis, Coleoptera būrio bestuburiai (ypač Limnius volckmari, Panzer) buvo tarp gausesnių ar dominavo natūraliose Nevèžio upès atkarpose miške.

Gauti duomenys rodo, kad chironomidai Cricotopus algarum (Kieffer) vyravo tiesintose upiu atkarpose (4 lentelè). V. Pliūraitès ir V. Kesmino duomenimis (2010), šie chironomidai buvo gausiai sutinkami natūralioje ir tiesintoje Mūšos upès atkarpose visais metų sezonais. Spenglos ir Amarnios upių tiesintose atkarpose gausu buvo lašalų Caenis 
macrura, Stephens (atitinkamai 24,4 \% ir 14,2 \%). Minèta lašalų rūšis Mūšos upès tiesintoje atkarpoje rudenį sudare 35,6 \% (viso makrozoobentoso gausumo) (Pliūraite, Kesminas, 2010).

Makrozoobentoso rūšinès sudèties klasterinè analizè, atlikta Bray-Curtis metodu, suskirstè tirtų upių atkarpas $\mathfrak{i}$ dvi grupes pagal upès vagos formą: pirma, upių atkarpos miške su natūralia vaga, antra, su tiesinta vaga (3 pav.). Klasterinè analizė parodė, kad pagal makrozoobentoso rūšinę sudètị labiausiai panašios Spenglos ir Amarnios upių natūralios atkarpos miške (63,1 \%) bei Grūdos ir Amarnios upių tiesintos atkarpos laukuose (58,5\%). Tik Spenglos ir Amarnios upių natūraliose atkarpose miške buvo aptikta lašalų Heptagenia sulphurea (Müller), Serratella ignita (Poda), ankstyvių Isoperla grammatica (Poda), apsiuvu Brachycentrus subnubilus Curtis, Ecnomus tenellus (Rambur). Antroje grupejje, kurią sudare tiesintos upių atkarpos, vyravo chironomidai Cricotopus algarum (Kieffer).

Bendras makrozoobentoso gausumas tirtų upių atkarpose kito nuo $640 \pm 17$ ind. $\mathrm{m}^{-2}$ iki $4180 \pm 45$ ind. $m^{-2}$ (4 pav.). Didžiausias makrozoobentoso gausumas buvo Spenglos upès natūralioje atkarpoje miške, kurị lèmé didelis apsiuvų lervų gausumas. Mažiausias makrozoobentoso gausumas nustatytas Grūdos upès tiesintoje atkarpoje laukuose. Nustatyta, kad bendras makrozoobentoso gausumas tirtų upių natūraliose atkarpose miške buvo statistiškai patikimai didesnis nei tiesintose upiu atkarpose laukuose (ANOVA: $F=508189,8$, $\mathrm{p}=0,00001 ; 4$ pav.). T. L. Kennedy ir T. F. Turner (2011) duomenimis, vidutinis makrozoobentoso

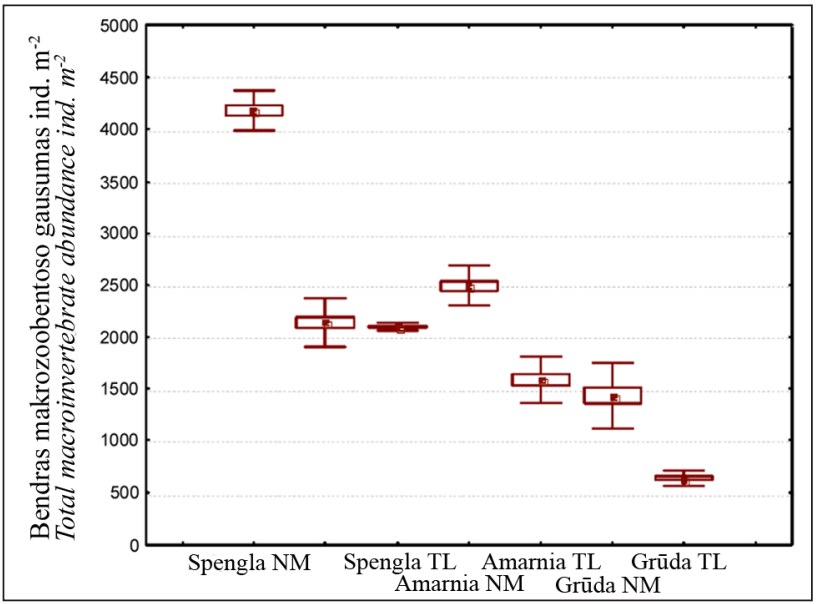

4 pav. Bendras makrozoobentoso gausumas tirtose upèse (NM - natūrali upès atkarpa miške, TM - tiesinta

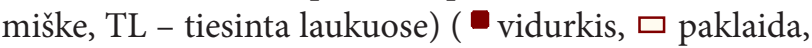
工 0,95 pasikliovimo intervalai)

Fig. 4. Total macroinvertebrate abundance in the investigated streams (NM - natural sites in the forest, $T M$ - straightened sites in the forest, TL - straightened sites in the field) ( mean, $\square \pm S E$, 工0.95 Conf. Interval)

gausumas tiesintoje upès atkarpoje buvo $50 \%$ mažesnis nei natūralioje.

Lašalų (Ephemeroptera) (ANOVA: $F=97051,3$, $p=0,00001$ ), apsiuvu (Trichoptera) (ANOVA: $F=94760,5, p=0,00001$ ), EPT (ANOVA: $F=47005,6, p=0,00001$ ), vabalų lervų (Coleoptera) (ANOVA: $F=476,3, p=0,00001$ ) gausumas tirtų upių natūraliose atkarpose miške buvo statistiškai patikimai didesnis nei tiesintose upiu atkarpose (5 pav.). Ankstesniais tyrimais nustatyta,

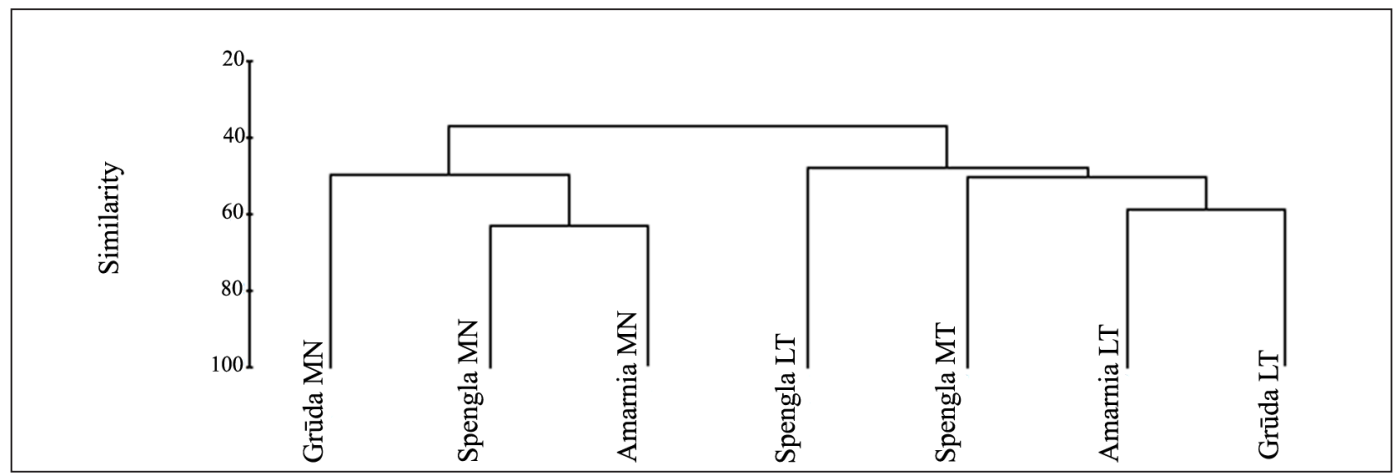

3 pav. Upių klasifikavimas pagal makrozoobentoso rūšinę sudètị (NM - natūrali upès atkarpa miške, TM - tiesinta miške, TL - tiesinta laukuose)

Fig. 3. Bray-Curtis index cluster analysis dendrogram showing similarity between macroinvertebrate abundances at the sampling sites of the investigated streams (NM - natural sites in the forest, TM - straightened sites in the forest, TL - straightened sites in the field) 


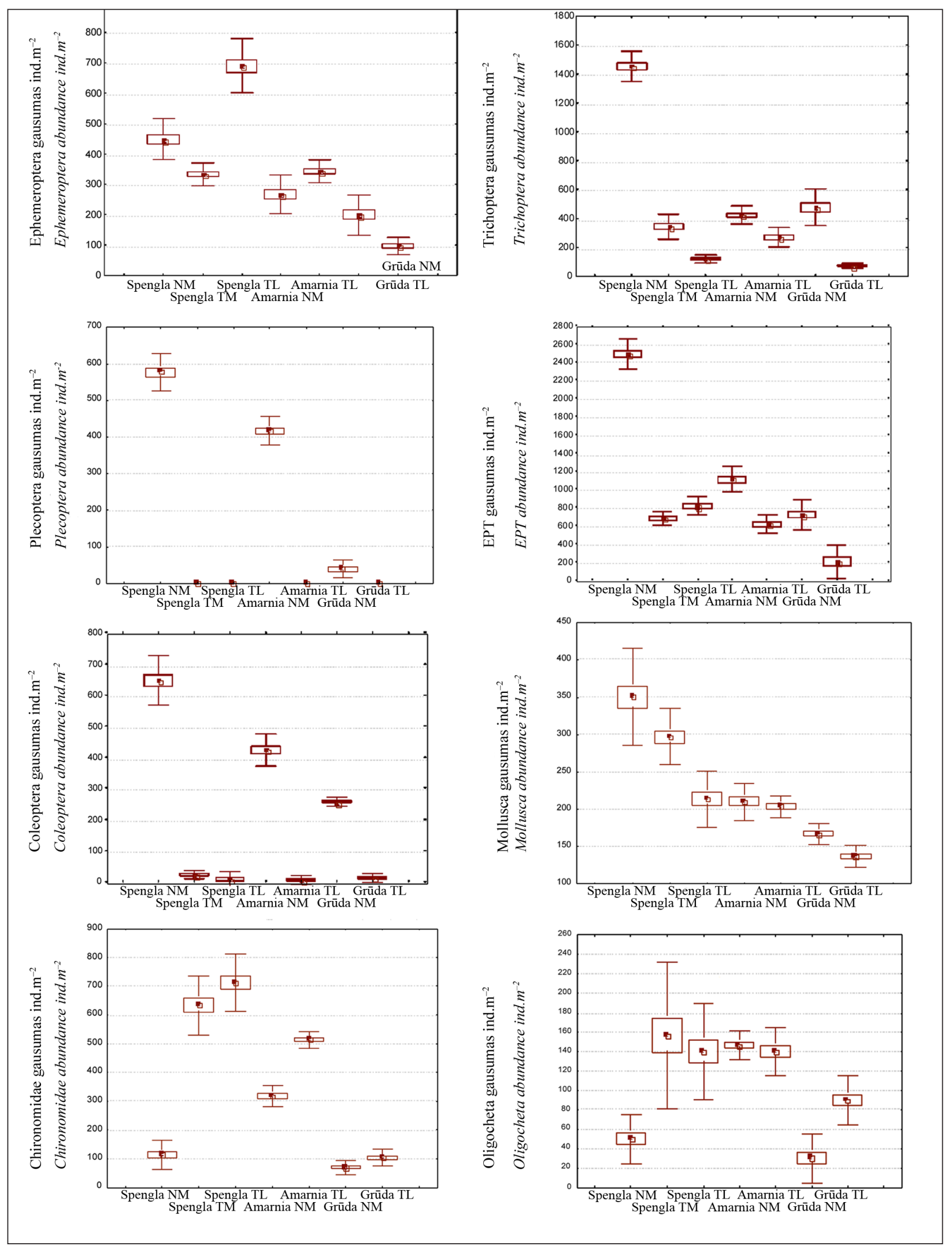

5 pav. Skirtingų makrobestuburių grupių gausumas tirtose upèse (NM - natūrali upès atkarpa miške, $\mathrm{TM}$ - tiesinta miške, TL - tiesinta laukuose) ( vidurkis, $\square$ paklaida, Ipasikliovimo intervalai)

Fig. 5. Distribution of values of selected macroinvertebrate metrics in the investigated streams (NM - natural sites in the forest, $T M$ - straightened sites in the forest, $T L$ - straightened sites in the field) (-mean, $\square \pm S E$, I 0.95 Conf. Interval) 
kad apsiuvų gausumas Mūšos upès natūralioje atkarpoje buvo taip pat statistiškai patikimai didesnis nei tiesintoje atkarpoje (Pliūraite, Kesminas, 2010). S. L. Rios ir R. C. Bailey (2006) tyrimais įrodè, kad miško paunksnè padidina EPT rūšių gausą ir įvairovę vandens telkiniuose, todèl mūsų tyrimų duomenimis, natūraliose upių atkarpose miške ir nustatytas statistiškai patikimai didesnis EPT rūšių gausumas. Pagal S. R. M. Couceiro ir kt. (2007), miškų išnaikinimas upių pakrantèse veikia makrobestuburių fauną panašiai kaip vandens užterštumas, t. y. sumažeja jų rūšių ịvairove, supaprastejja vabzdžių populiacijų i̇vairovè.

Atsparių taršai chironomidų gausumas (ANOVA: $F=55802,9, p=0,00001)$ Spenglos ir Amarnios upių tiesintose atkarpose buvo statistiškai patikimai didesnis nei natūraliose atkarpose miške (5 pav.). Grūdos upeje statistiškai patikimų skirtumų tarp tyrimo vietų nenustatyta. Kad chironomidai gausesni tiesintoje upès atkarpoje, įrodè ir kiti mokslininkai (Pliūraitè, Kesminas, 2010). Atsparių taršai mažašerių žieduotųjų kirmèlių gausumas (ANOVA: $F=13268,0, p=0,00001$ ) Spenglos ir Grūdos upių tiesintose atkarpose buvo statistiškai patikimai didesnis nei natūraliose atkarpose miške (5 pav.). Amarnios upeje statistiškai patikimų skirtumų tarp tyrimo vietų nenustatyta. Mūšos upès tiesintoje atkarpoje mažašerių žieduotuju kirmèlių gausumas taip pat buvo statistiškai patikimai didesnis nei natūralioje atkarpoje (Pliūraitè, Kesminas, 2010). Moliusku gausumas (ANOVA:
$F=221182,2, p=0,00001)$ Spenglos ir Grūdos upių natūraliose atkarpose miške buvo statistiškai patikimai didesnis nei tiesintose upių atkarpose laukuose. Amarnios upeje statistiškai patikimų skirtumų tarp tyrimo vietų nenustatyta.

Pagal santykinį makrozoobentoso gausumą tiesintos upių atkarpos skyrèsi nuo natūralių pagal vyraujančias makrobestuburių organizmų grupes. Spenglos ir Grūdos upių natūraliose atkarpose miške pagrindinę makrozoobentoso dali pagal santykinị gausumą sudarè apsiuvos, o Amarnios - apsiuvos ir ankstyvès (6 pav.). Spenglos upès tiesintoje atkarpoje miške ir Amarnios upès tiesintoje atkarpoje laukuose vyravo chironomidai, o Spenglos tiesintoje atkarpoje laukuose vyravo chironomidai ir lašalai (6 pav.). Grūdos upès tiesintoje atkarpoje laukuose neišryškejo vienos makrozoobentosinių organizmų grupès vyravimas. Minètoje upejje gausu buvo mažašerių kirmèlių, moliuskų, chironomidų, lašalų.

Nustatyta, kad upių makrozoobentoso bendrijų struktūrą vandens telkiniuose visų pirma veikia fiziniai aplinkos veiksniai: temperatūra, srovès greitis, gylis (Lods-Crozet ir kt., 2001). Vandens temperatūra yra vienas svarbiausių fizinių veiksnių, lemiančių bestuburių gyvūnų vystymosi ir gyvenimo procesus, funkcionavimą bendrijose (Vannote, Sweeney, 1980), paplitimą skirtingo tipo ir klimatinio režimo upèse ir upių baseinuose (Wiley ir kt., 1997). Vandens temperatūra teigiamai veikia makrozoobentoso gausumą (Milner ir kt., 2001),

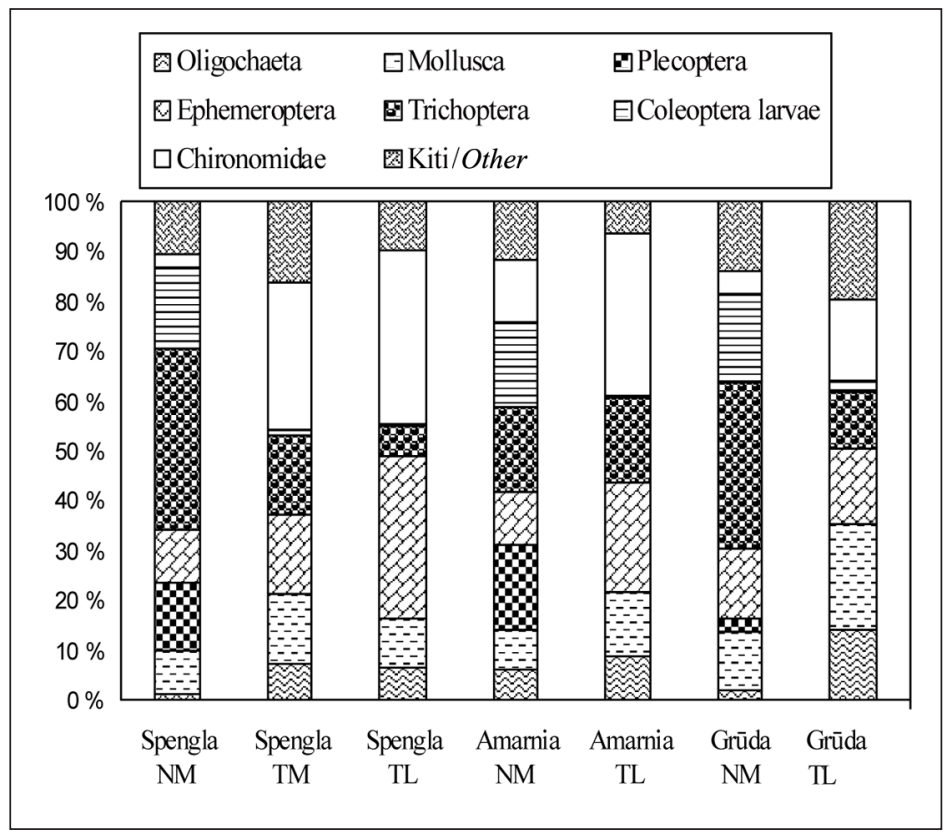

6 pav. Santykinis makrobestuburių gausumas tirtose upèse (NM - natūrali upès atkarpa miške, TM - tiesinta miške, TL - tiesinta laukuose)

Fig. 6. Relative abundance of macroinvertebrates in the investigated streams (NM - natural sites in the forest, TM - straightened sites in the forest, $T L$-straightened sites in the field) 
dugno gyvūnijos rūšiu skaičių (Friberg ir kt., 2001) bei vabzdžių rūšių gausumą (Ward, 1986). J. A. Camargo ir N. J. Voelz (1998) taip pat nustatè teigiamą koreliacinį ryšs tarp vandens temperatūros ir makrozoobentoso taksonų skaičiaus $(r=0,52)$ bei bendro makrozoobentoso gausumo $(r=0,51)$. Mūsų duomenimis, nustatyta teigiamas statistiškai patikimas koreliacinis ryšys tarp vandens temperatūros upese ir bendro makrozoobentoso taksonų skaičiaus, apsiuvų rūšių skaičiaus, bendro makrozoobentoso gausumo, chironomidų ir mažašerių žieduotųjų kirmèlių gausumo (5 lentelè).

Srovès poveikis atskiroms makrozoobentoso grupèms yra skirtingas. Apsiuvos gyvena ten, kur didesnis srovès greitis, o moliuskai - kur mažesnis. Didelis srovès greitis trukdo moliuskams aktyviai filtruoti (Ackerman, 1999). Mūsų tyrimų duomenimis, ankstyvių $(r=0,48)$ ir vabalų lervų $(r=0,62)$ gausumas teigiamai koreliavo su srovès greičiu, o lašalų, chironomidų ir mažašerių kirmèlių - neigiamai (atitinkamai $r=0,62 ; r=0,80 ; r=0,54$ ).
Nustatyta, kad upių debito svyravimai, veikiantys dugno buveinių stabilumą, labai veikia makrozoobentoso ịvairovę ir gausumą (Vieira ir kt., 2004). Mūsų duomenimis, egzistuoja teigiamas statistiškai patikimas koreliacinis ryšys tarp debito ir apsiuvų rūšių skaičiaus, bendro makrozoobentoso gausumo, apsiuvų, vabalų lervų gausumo bei neigiamas tarp debito ir chironomidu ir mažašerių žieduotųjų kirmèlių gausumo (5 lentelè). Kitų mokslininkų (Bernotienè, Višinskienė, 2008) duomenimis, taip pat nustatyta teigiama koreliacija tarp upés debito ir ankstyvių, apsiuvų, vabalų lervų gausumo.

Mūsų tyrimų duomenimis, tiesioginis saulès patekimas $\mathfrak{i}$ upès vagą turèjo neigiamos ịtakos bendram makrozoobentoso taksonų skaičiui, EPT taksonų skaičiui, apsiuvų rūšių skaičiui, ankstyvių, vabalų lervų gausumui (5 lentelè). D. B. Arscott duomenimis (2003), miško upeliuose apsiuvų rūšių dažniausiai būna daugiau negu atviroje vietoveje tekančiuose upeliuose. Mūsų

5 lentelè. Spirmeno rangų koreliacija tarp makrobestuburių rodiklių ir aplinkos parametrų

Table 5. Spearman rank correlation between macroinvertebrate metrics and environment parameters

\begin{tabular}{|c|c|c|c|c|c|}
\hline $\begin{array}{l}\text { Rodiklis } \\
\text { Metrics }\end{array}$ & $\begin{array}{l}\text { Tempera- } \\
\text { tūra }{ }^{\circ} \mathrm{C} \\
\text { Water tem- } \\
\text { perature }\end{array}$ & $\begin{array}{c}\text { Srovès } \\
\text { greitis } \mathrm{m} / \mathrm{s} \\
\text { Current } \\
\text { velocity }\end{array}$ & $\begin{array}{c}\text { Tiesioginis } \\
\text { saulès pateki- } \\
\text { mas ì vagą \% } \\
\text { Direct sun pass }\end{array}$ & $\begin{array}{c}\text { Vagos užaugimas } \\
\text { augalija \% } \\
\text { River-bed over- } \\
\text { growth with plants }\end{array}$ & $\begin{array}{c}\text { Debitas } \\
\mathbf{m}^{3} / \mathrm{s} \\
\text { Discharge }\end{array}$ \\
\hline $\begin{array}{c}\text { Bendras taksonu skaičius } \\
\text { Total macroinvertebrate } \\
\text { taxa number }\end{array}$ & 0,51 & 0,52 & $-0,81$ & $-0,69$ & - \\
\hline $\begin{array}{l}\text { EPT taksonų skaičius } \\
\text { EPT taxa number }\end{array}$ & - & 0,48 & $-0,73$ & $-0,76$ & - \\
\hline $\begin{array}{l}\text { Trichoptera rūšių skaičius } \\
\text { Trichoptera species number }\end{array}$ & 0,55 & 0,49 & $-0,75$ & $-0,53$ & 0,59 \\
\hline $\begin{array}{l}\text { Bendra gausa } \\
\text { Total abundance }\end{array}$ & 0,51 & - & - & - & 0,46 \\
\hline $\begin{array}{c}\text { EPT gausa } \\
\text { EPT abundance }\end{array}$ & - & - & - & $-0,65$ & 0,53 \\
\hline $\begin{array}{c}\text { Ephemeroptera gausa } \\
\text { Ephemeroptera abundance }\end{array}$ & - & - & 0,43 & & - \\
\hline $\begin{array}{c}\text { Plecoptera gausa } \\
\text { Plecoptera abundance }\end{array}$ & - & 0,48 & $-0,59$ & - & 0,55 \\
\hline $\begin{array}{c}\text { Trichoptera gausa } \\
\text { Trichoptera abundance }\end{array}$ & - & - & $-0,54$ & - & 0,66 \\
\hline $\begin{array}{c}\text { Coleoptera gausa } \\
\text { Coleoptera abundance }\end{array}$ & - & 0,62 & $-0,70$ & - & 0,74 \\
\hline $\begin{array}{c}\text { Chironomidae gausa } \\
\text { Chironomidae abundance }\end{array}$ & 0,52 & $-0,80$ & 0,57 & - & $-0,58$ \\
\hline $\begin{array}{c}\text { Oligochaeta gausa } \\
\text { Oligochaeta abundance }\end{array}$ & 0,69 & $-0,54$ & - & - & $-0,60$ \\
\hline
\end{tabular}


atlikti tyrimai ši teigini patvirtina. Spenglos ir Amarnios upių natūraliose atkarpose miške apsiuvų rūšių skaičius buvo dvigubai didesnis negu tiesintose upių atkarpose laukuose. Nustatytas neigiamas statistiškai patikimas koreliacinis ryšys tarp apsiuvų rūšių skaičiaus ir tiesioginio saulès patekimo i̇ upès vagą $(r=-0,75)$.

Tarp cheminių medžiagų kiekio vandenyje ir makrozoobentoso rodiklių koreliacinių patikimų ryšių nenustatyta.

Tiesintose upių vagose žolinė augalija sukelia patvanką ir mažina tekejjimo greitị, o sulètèjus tèkmei upèse, iš aukštupio nešami nešmenys bei su paviršiniu nuotekiu atneštos grunto dalelès formuoja sąnašų sankaupas (Maziliauskas ir kt. 2011). Sąnašomis užneštoje upès vagoje susidaro palankios sąlygos vystytis vandens augalijai, kuri trukdo tèkmei, dèl to ne tik išnyksta daugelis reofilinių makrobestuburių rūšių, bet ir kinta likusių pasiskirstymas, nuo to priklauso ir kitų bestuburių ir stuburinių gyvūnų paplitimas ir gyvenimo kokybè.

\section{IŠVADOS}

1. Nustatyta, kad makrozoobentoso rūšinei ịvairovei, gausumui ir vyraujančioms rūšims turi ittakos upès vagos struktūra. Tirtų upių natūraliose atkarpose minèti rodikliai buvo didesni, palyginti su tiesintomis atkarpomis toje pačioje upeje.

2. Tirtu triju upiu natūraliose ir tiesintose atkarpose nustatyti 72 makrozoobentoso taksonai, priklausantys 48 šeimoms. Natūraliose upių atkarpose miške vyravo apsiuvos Brachycentrus maculatus, o tiesintose upiu atkarpose - chironomidai Cricotopus algarum.

3. Bendras makrozoobentoso gausumas, lašalų, apsiuvų, EPT, vabalų lervų kiekis tirtų upių natūraliose atkarpose buvo statistiškai patikimai didesnis nei tiesintose upių atkarpose. Atsparių taršai chironomidų lervų gausumas Spenglos ir Amarnios upių tiesintose atkarpose buvo statistiškai patikimai didesnis nei natūraliose atkarpose.

4. Aplinkos parametrai veikè bendrą ir EPT makrozoobentoso taksonų skaičių, atskirų makrozoobentoso grupių paplitimą tirtų upių atkarpose.

Gauta 20120916

Priimta 20130122

\section{LITERATŪRA}

1. Ackerman J. D. 1999. The effect of velocity on the filter feeding of zebra mussels (Dreissena polymorpha and D. bugensis): Implications for Trophic Dynamics. Canadian Journal of Fisheries and Aquatic Sciences. Vol. 56. P. 1551-1561.

2. Arbačiauskas K., Gaigalis K., Šmitienè A., Višinskienè G. 2004. Klimato, hidrologinių ir hidrocheminių veiksnių poveikis Graistupio upelio bentofaunai. Lietuvos žemés ūkio universiteto ir Lietuvos žemés ükio universiteto vandens ükio instituto mokslo darbai. Nr. 27(47). P. 38-44.

3. Arscott D. B., Keller B., Tockner K., Ward J. V. 2003. Habitat structure and Trichoptera diversity in two headwater flood plains, N. E. Italy. International Review of Hydrobiology. Vol. 88. No. 3-4. P. 255273.

4. Bernotienè R., Višinskienè G. 2008. Bentosiniu bestuburių pasiskirstymo ypatumai Neries ir Šventosios upių intakuose. Žuvininkysté Lietuvoje. T. VIII. P. 207-217.

5. Bis B., Zdanowicz A., Zalewski M. 2000. Effect of catchment properties on hydrochemistry, habitat complexity and invertebrate community structure in a lowland river. Hydrobiologia. Vol. 422(423). P. 369-387.

6. Camargo J. A., Voelz N. J. 1998. Biotic and abiotic changes along the recovery gradient of two impounded rivers with different impoundment use. Environmental Monitoring and Assessment. Vol. 50. P. 143-158.

7. Chapman L. J., Chapman C. A. 2002. Tropical forest degradation and aquatic ecosystems: our current state and knowledge. In: M. J. Collares-Pereira, I. G. Cowx, M. M. Coelho (Eds.). Conservation of Freshwater Fishes: Options for the Future. Blackwell, Oxford: Fishing News Books. P. 235-249.

8. Couceiro S. R. M., Hamada N., Lur S. L. B., et al. 2007. Deforestation and sewage effects on aquatic macroinvertebrates in urban streams in Manaus, Amazonas. Brazilian Hydrobiologia. Vol. 575. P. 271-284.

9. Czachorowski S., Pietrazk L. 2003. Klucz do oznaczania rodzin chruścików (Trichoptera) występujacych w Polsce. Olsztyn: Mantis.

10. Deathl R. G., Winterbourn M. J. 1995. Diversity patterns in stream benthic invertebrate communities: the influence of habitat stability. Ecology. Vol. 76. P. 1446-1460.

11. Friberg N., Milner A. M., Svendsen L. M., et al. 2001. Macroinvertebrate stream communities along regional and physico-chemical gradients in Western Greenland. Freshwater Biology. Vol. 46. P. 1753-1764.

12. Fruget J. F., Dessaix J. 2001. Biodiversity of macroinvertebrate communities as describer of 
hydraulic variability: the Middle Rhône River. Revue des Sciences de l'Eau. Vol. 15(1). P. 209-221.

13. Gailiušis B., Jablonskis J., Kovalenkovienė M. 2001. Lietuvos upes. Hidrografija ir nuotèkis. Kaunas: Lietuvos energetikos institutas. $792 \mathrm{p}$.

14. Horne A. J. 2003. Wetlands and Rivers: Ecology and Management, CE 118 Class Reader. Berkeley, USA: Department of Civil and Environmental Engineering, University of California.

15. Kasangaki A., Chapman L. J., Balirwa J. 2008. Land use and the ecology of benthic macroinvertebrate assemblages of high-altitude rainforest streams in Uganda. Freshwater Biology. Vol. 53. P. 681-697.

16. Kennedy T. L., Turner T. F. 2011. River channelization reduces nutrient flow and macroinvertebrate diversity at the aquatic terrestrial transition zone. Ecosphere. Vol. 2(3). P. 1-13.

17. Kerans B. L., Karr J. R. 1994. A benthic index of biotic integrity (B-IBI) for rivers of the Tennessee Valley. Ecological Applications. Vol. 4. P. 768-785.

18. Kleemola S., Söderman G. 1993. Manual for Integrated Monitoring. Programme Phase 1993-1996. Hydrobiology of Streams. Helsinki: National Board of Water and the Environment. P. 67-68.

19. Lietuvos standartai. 2010. Paviršiniu vandens telkinių būklès nustatymo metodika. Valstybès žinios. No. 29-1363. P. 99-109.

20. Lods-Crozet B., Castella E., Cambin D., et al. 2001. Macroinvertebrate community structure in relation to environmental variables in a Swiss glacial stream. Freshwater Biology. Vol. 46. No. 12. P. 1641-1661.

21. Maziliauskas A., Baublys R., Gegužis R. 2011. Deformaciniai procesai sureguliuotų upių vagose. Vandens ūkio inžinerija. Vol. 39(59). P. 5-13.

22. Maxted J. R., Barbour M. T., Gerritsen J., et al. 2000. Assessment framework for mid-Atlantic coastal plain streams using benthic macroinvertebrates. Journal of the North American Benthological Society. Vol. 19. P. 128-144.

23. Milner A. M., Taylor R. C., Winterbourn M. J. 2001. Longitudinal distribution of macroinvertebrates in two glacier-fed New Zealand rivers. Freshwater Biology. Vol. 46. P. 1765-1775.

24. Negishi J. N., Negishi M., Inone M., Nunokawa M. 2002. Effects of channelization on stream habitat in relation to a spate and flow refugia for macroinvertebrates in Northern Japan. Freshwater Biology. Vol. 47. P. 1515-1529.

25. Opredelitel presnovodnykh bezpozvonochnykh Rossii (plankton $i$ bentos). 1977. Pod. red. L. A. Kutikovoy i Ya. I. Starobogatoba. Leningrad: Gidrometeoizdat.

26. Opredelitel presnovodnykh bezpozvonochnykh Rossii $i$ sopredelnykh teritoriy. Sankt-Peterburg: Nauka. 1997. T. 3; 1999. T. 4; 2001. T. 5.
27. Pankratova B. YA. 1959. Fauna lichinok tendipedid (khironomid) vodomov baseyna reki Venty. Rybnoe khozyaystvo vnutrennikh vodoemov Latv. SSR. Riga. S. 181-197.

28. Pankratova B. YA. 1970. Lichinki i kukolki komarov podsemeystvo Orthocladiinae fauny SSSR (Diptera, Chironomidae $=$ Tendipedidae). Leningrad: Nauka.

29. Pankratova B. YA. 1977. Lichinki i kukolki komarov podsemeystvo Podonominae $i$ Tanypodinae fauny SSSR (Diptera, Chironomidae $=$ Tendipedidae $)$. Leningrad: Nauka.

30. Pankratova B. YA. 1983. Lichinki i kukolki komarov podsemeystvo Chironominae fauny SSSR (Diptera, Chironomidae $=$ Tendipedidae) . Leningrad: Nauka.

31. Pastuchova Z. 2006. Macroinvertebrate assemblages in conditions of low-discharge streams of the Cerová vrhovina highland in Slovakia. Limnologica. Vol. 36. P. 241-250.

32. Pliūraitè V. 2007. Macroinvertebrate seasonal dynamics in the Vilnia river (Lithuania). Acta hydrobiologica Lituanica. Vol. 17(4). P. 299-312.

33. Pliūraite V., Kesminas V. 2010. Response of benthic macroinvertebrates to agricultural pollution and channelization in the Mūša river, Lithuania. Fresenius Environmental Bulletin. Vol. 19. No. 12a. P. 2929-2937.

34. Rios S. L., Bailey R. C. 2006. Relationship between riparian vegetation and stream benthic communities at three spatial scales. Hydrobiologia. Vol. 553. P. 153-160.

35. Rosenberg D. M., Resh V. H. 1993. Introduction to freshwater biomonitoring and benthic macroinvertebrates. In: D. M. Rosenberg, V. H. Resh (Eds.). Freshwater Biomonitoring and Benthic Macroinvertebrates. New York: Chapman and Hall. P. 1-9.

36. Sandin L., Johnson R. K. 2000. The statistical power of selected indicator metrics using macroinvertebrates for assessing acidification and eutrophication of running waters. Hydrobiologia. Vol. 422/423. P. 233-243.

37. Smiley P. C. Jr., Dibble E. D. 2008. Influence of spatial resolution on assessing channelization impacts on fish and macroinvertebrate communities in a warm water stream in the southeastern United States. Environmental Monitoring and Assessment. Vol. 138. P. 17-29.

38. Šivickis P. 1960. Lietuvos moliuskai ir ju apibūdinimas. Vilnius.

39. Vannote R. I., Sweeney B. W. 1980. Geographic analysis of thermal equilibria: a conceptual model for evaluating the effect of natural and modified thermal regimes on aquatic insect communities. American Naturalist. Vol. 115. P. 667-695.

40. Vieira N. K. M., Clements W. H., Guevara L. S., Jacobs B. F. 2004. Resistance and resilience of stream insect communities to repeated hydrological 
disturbance after a wildfire. Freshwater Biology. Vol. 49. P. 1243-1259.

41. Virbickas T., Pliūraitė V., Kesminas V. 2011. Impact of agricultural land use on macroinvertebrate fauna in the Nevèžis River (Nemunas basin, Lithuania). Polish Journal of Environmental Studies. Vol. 20. No. 5. P. 1327-1334.

42. Ward J. V. 1986. Altitudinal zonation in a Rocky Mountain stream. Archiv für Hydrobiology. Suppl. Vol. 74. P. 133-199.

43. Wildhaber M. L., Schmitt C. S. 1998. Indices of benthic community tolerance in contaminated great lakes sediments: Relations with sediment contaminant concentrations, sediment toxicity and the sediment quality triad. Environmental Monitoring and Assessment. Vol. 49. P. 23-49.

44. Wiley M. J., Kochler S. L., Seelbach P. W. 1997. Reconciling landscape and local views of aquatic communities: lessons from Michigan trout streams. Freshwater Biology. Vol. 37. P. 133-148.

\section{Ramūnas Gegužis}

\section{BENTHIC MACROINVERTEBRATE \\ COMMUNITIES IN NATURAL AND \\ CHANNELIZED SITES OF MERKYS RIVER BASIN STREAMS}

Sum mary

The present study contains the results of an investigation of the abundance and taxonomic composition of benthic macrofauna, collected in natural and straightened sites of 3 streams of the basin of the Merkys River. The current velocity, water discharge, riverbed overgrowth with plants and direct sun pass were highest in the natural sites of the investigated streams and lowest in the straightened sites of the investigated streams. A total of 72 macroinvertebrate taxa belonging to 48 families were identified in the investigated sites of the streams. 18 macroinvertebrate taxa were found only in the natural sites in the forest of the investigated streams and 7 were found in the straightened sites of the investigated rivers. The data obtained showed that the total taxon number and EPT taxon number of macroinvertebrates in the same stream natural sites in the forest were higher than those in the straightened stream sites. Caddisflies Brachycentrus maculatus dominated in the natural sites of the streams Spengla and Amarnia, chironomids Cricotopus algarum dominated in the straightened sites of all investigated streams. It was shown that the total abundance of macroinvertebrates in the natural sites in the forest of the investigated streams was significantly higher in comparison with the straightened sites in the field. The highest total abundance of macroinvertebrates was determined in the natural site in the forest of the stream Spengla (4 $180 \pm 45$ ind. $\mathrm{m}^{-2}$ ) and the lowest abundance was found in the straightened site in the field of the stream Grūda $\left(640 \pm 17\right.$ ind. $\left.\mathrm{m}^{-2}\right)$. The data of this investigation showed that the abundance of mayflies (Ephemeroptera), caddisflies (Trichoptera), EPT was significantly higher in the natural sites in the forest of the investigated streams, while the percentage of pollution-tolerant Chironomidae was higher in the straightened sites in the field of the streams Spengla and Amarnia.

Key words: macroinvertebrate, natural, straightened sites, streams 